\title{
Developing Scientific Practices in Primary School: Benzene Ring Heuristic (BRH) Application
}

\author{
Yagmur Gokbulak' \& Burcu Senler $\bowtie 2$ \\ 1,2 Department of Elementary Education, Mugla Sitki Kocman University, Mugla, Turkey \\ $\bowtie$ bsenler@mu.edu.tr
}

\begin{abstract}
This study aims to develop primary-school students' understanding of the scientific practices in the Benzene Ring Heuristic (BRH) and to determine how BRH applications would affect student perceptions about science, scientific knowledge, and scientists. An interpretative qualitative research design was used in the study. The study group consisted of 9 fourth-grade students ( 6 girls, 3 boys) in a public primary school. To identify the students' thoughts and perceptions about science, scientific knowledge, and scientists, the study employed open-ended questions as well as the "Draw-a-Scientist Test". In addition, a poster activity was used to determine how well students understood the scientific practices in the BRH. The drawing test results showed that students drew scientists in general as female, young, most often with a neat-looking physical appearance in enclosed areas mainly representing a laboratory environment, and who is experimenting. An analysis of the posters produced by the students as part of the BRH suggested a certain amount of improvement. These results have educational implications and should be helpful for teachers and teacher educators to better understand the effects of using BRH in science education.
\end{abstract}

Keywords: scientific practices, benzene ring heuristic, primary school, fourth-grade students, interpretative qualitative research

How to Cite: Gokbulak, Y., \& Senler, B. (2021). Developing Scientific Practices in Primary School: Benzene Ring Heuristic (BRH) Application. Mimbar Sekolah Dasar, 8(3), 217-232. doi:https://doi.org/10.53400/mimbarsd.v8i3.32382.

INTRODUCTION In recent years, to emphasize the importance of students having a contemporary understanding of science and raising students as scientifically literate individuals, reforms have been made in the field of science education. These have been seen as one of the primary goals of science education in many different countries. From this point of view, the nature of science and scientific inquiry is one of the integral components of scientific literacy (Lederman, Lederman, \& Antink, 2013; Roberts, 2007). Considering the recent developments in the world, a great deal of importance is given to the scientific understanding of teacheris and students, and the necessity of developing teachers' and students' perceptions about the nature of science is emphasized in the reforms in the field of science education (Cakici, 2013).

The Family Resemblance Approach (FRA) is one of the approaches used to explain the nature of science. This approach argues that while the branches of science are similar to each other 
Yagmur Gokbulak \& Burcu Senler, Developing Scientific Practices in Primary School: Benzene Ring...

in some aspects, they differ from each other in some aspects, so each sub-discipline should be examined within itself. For this reason, FRA suggests that the nature of science should be examined with its own methodological, ontological, and epistemological differences (Erduran \& Dagher, 2014). "Scientific practices", one of the categories of FRA, contributes to the generation of scientific knowledge. Scientific practices consider scientific studies from epistemic, cognitive, and social-institutional perspectives. The Benzene Ring Heuristic (BRH) is a visual tool to explain scientific practices, and it has some similarities with The National Research Council (NRC) (2012) framework. For instance, the notions of reasoning, practices, explanations, models, and data are consistent across them. As such, using the BRH is a way to develop students' understanding of scientific practices.

\section{LITERATURE REVIEW}

An important issue in science education has to do with "the nature of science". While defined in many different ways, it most often refers to values and assumptions specific to the development of scientific knowledge (Lederman \& Zeidler, 1987). In general, the nature of science refers to the epistemology of science, "ways of knowing" science and scientific knowledge, and the values and beliefs specific to its development (Lederman, 1992).

An approach to this issue that has been promoted by Irzik and Nola (2014) is the Family Resemblance Approach (FRA), in which various aspects of science can be studied together as a harmonious whole. This approach has also been referred to as the "Reconceptualized Family Resemblance Approach to the Nature of Science" (RFN) (Erduran \& Dagher, 2014). According to the FRA, science consists of interconnected components that can be classified into 11 different categories: aims and values, methods and methodological rules, scientific knowledge, scientific practices, social values, scientific ethos, professional activities, social certification and dissemination, financial systems, social organizations and interactions, and political power structures. Included in these categories are epistemic, cognitive, and social practices used to obtain scientific knowledge and that constitute "scientific practices". A more recent term, "science practice", has been defined by Stroupe (2015) as "the learnable and valuable dimensions of disciplined work, implicit and explicit, that people develop over time in a specific place such as a laboratory, field station, or classroom". Understanding scientific practices help students to develop their understanding of the nature of science which helps to develop content knowledge (Driver, Leach, Millar, \& Scott, 1996; Peters, 2006) as well as procedural knowledge and epistemic understanding of science (Kuhn, Arvidsson, Lesperance, \& Corprew, 2017).

The NRC (2012) lists the following activities under the heading of scientific practices: asking questions for science and defining problems for engineering, developing and using models, planning and conducting research, analyzing and interpreting data, using mathematical and 
numerical thinking, creating explanations for science, designing engineering solutions, presenting arguments from evidence, obtaining information, evaluating, and communicating. Through the interrelated use of all these scientific practices, scientific knowledge is obtained. Collecting, organizing, classifying, and analyzing data are some of the scientific practices that reflect the scientific processes (M. Matthews, 2004), whereas other skills used in the scientific process-observing, experimenting, utilizing the modeling method, making predictions, explaining, and discussing - constitute scientific practices that reflect the epistemic, cognitive, and socio-institutional characteristics of science (Erduran \& Dagher, 2014). Erduran and Dagher (2014) have proposed a visual analogy for the holistic explanation and employment of scientific practices that comprise the FRA: The Benzene Ring Heuristic (BRH) (see Figure 1).

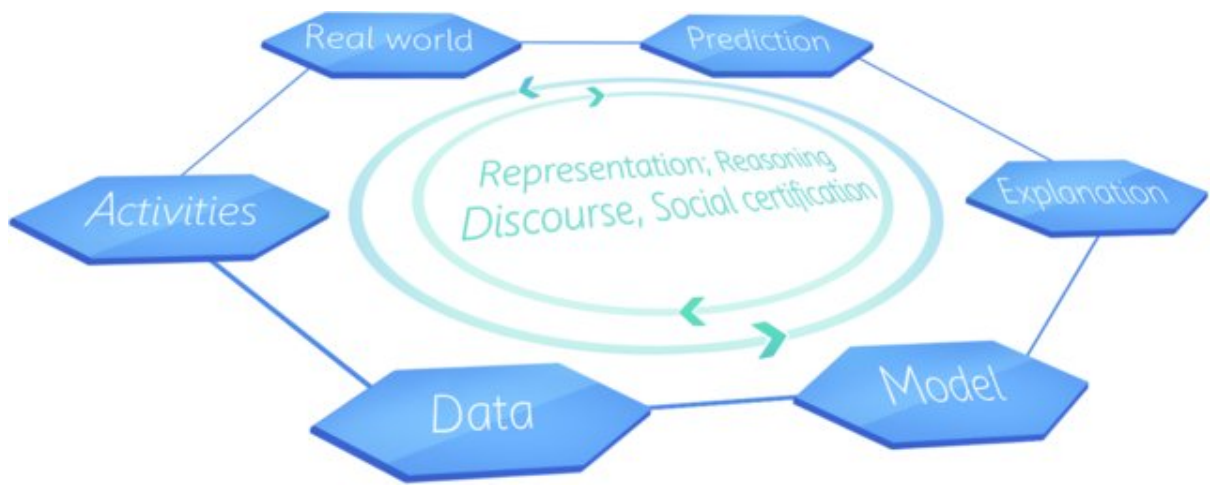

Figure 1. Benzene Ring Heuristic of scientific practices (Erduran \& Dagher, 2014, p. 82)

As Figure 1 displays, scientific practices are activities (i.e. observation, classification and experimentation), real-world, prediction, explanation, model, data, representation, reasoning, discourse, and social certification. The BRH illustrates the interconnectedness of the various components of scientific practices through the image of a benzene ring, an organic compound comprised of six carbon atoms attached in a ring by double bonds of electrons that are also spread out along the inside of the ring. The carbon atoms of the benzene ring represent the epistemic and cognitive components of science (real-world, prediction, explanation, modeling, data, and activities), whereas the electrons and double bonds refer to the social environment (representation, reasoning, discourse, and social certification). As all scientific processes involve representation, reasoning, discourse, and social certification, they are located in the middle of the figure. A significant aspect of the Benzene Ring heuristic is that "(a) it communicates a dynamic set of interactions between the data, models, explanations, and predictions that underlie the characterizations of phenomena occurring in the real world, and (b) it integrates the social-institutional and cognitive processes that mediate such interactions through discursive practices such as argumentation as well as norms such as social certification" (Erduran \& Dagher, 2014, p. 85). 
Yagmur Gokbulak \& Burcu Senler, Developing Scientific Practices in Primary School: Benzene Ring...

The BRH illustrates the holistic nature of the epistemic, cognitive, and social components of science. The heuristic provides visual tools for teachers in a coordinated fashion and motivates students (Erduran \& Dagher, 2014). It can also be used as an educational aid, and a pedagogical tool for teaching and learning about scientific practices (Erduran \& JimenezAleixandre, 2008; Kaya \& Erduran, 2016b). Accordingly, the BHR can be viewed as a holistic and visual representation that science teachers can use to create a more dynamic relationship between scientific practices and many kinds of scientific activities. Especially for the young students, it may help them to understand scientific practices easier.

A review of the literature on the nature of science indicates that despite the many studies that have been conducted on the subject, only a limited number have investigated the issue from an FRA perspective concerning science education. These include studies focused on Turkey's middle-school science curricula (e.g. Kaya \& Erduran, 2016b, 2016a), middle-school students (e.g. Cilekrenkli, 2019; Karabas, 2017), and pre-service science teachers (e.g. Kaya, Erduran, Akgun, \& Aksoz, 2017). Very few studies (e.g. Atas \& Senler, 2018) have been conducted with primary-school students that examine the BRH and how it can help students understand scientific practices. Therefore, the present study was conducted to develop primary-school students' understanding of the scientific practices in the BRH and to determine how BRH applications would affect student perceptions about science, scientific knowledge, and scientists.

\section{METHOD}

\section{Research Design}

According to Merriam (2002), interpretive qualitative research involves the construction of meaning, with the behavior and thoughts of the individual as they construct their interactions with their social world defining reality. This study examined how students interpret scientific practices along with science, scientific knowledge, and scientists and develop their interpretation with experiences. Therefore, an interpretive qualitative research design was employed.

\section{Study Context}

Turkey has a highly centralized educational bureaucracy and administration in which all aspects of public education are under the control of the Ministry of Education (MONE). All public schools in Turkey must implement the national curriculum prepared by the MONE's Board of Education using textbooks selected by the Board of Education and following a detailed teaching manual also provided by the Board in place of individual lesson plans. According to the MONE (2018), the primary-school science curriculum is a student-centered 
curriculum with a spiral design model focused on scientific literacy. Science lessons are scheduled for three 40-minute class sessions per week.

\section{Participants}

The study was conducted in a public school affiliated with the MONE and thus following a centralized national curriculum in Turkey. Convenience-sampling was utilized in this study. One of the researchers was a fourth-grade teacher and her students were selected as participants. The study was approved by the MONE Ethics Committee and the administrator of the participating school in terms of ethical issues. All students in the classroom volunteered to participate in the study, so the study group consisted of 9 fourth-grade students 6 girls and 3 boys). The parents of the participating students gave their informed consent since the students were under legal age. The anonymity of the school and the participants was ensured. The students formed themselves into groups of 3 students, which they identified by the self-selected names of "Storm", "Flash" and "A".

\section{Data Collection Tools}

To identify the students' thoughts and perceptions about science, scientific knowledge, and scientists, the study employed open-ended questions as well as the "Draw-a-Scientist Test". In addition, a poster activity was used to determine how well students understood the scientific practices in the BRH.

\section{Open-Ended Questions}

The open-ended questions consisted of the following three questions, which were devised by the researchers and validated by an expert:

1. What do you think science is? What comes to mind when you think of science?

2. How can scientific knowledge be obtained?

3. How do scientists work / what do they do?

\section{Draw A-Scientist Test (DAST)}

Developed by Chambers (1983) based on the findings of an 11-year study conducted between 1966 and 1977, the Draw-A-Scientist Test (DAST) is the preferred measurement tool for identifying peoples' perceptions of scientists (Senel \& Aslan, 2014). The DAST invites individuals to express their perceptions and thoughts about scientists by drawing a picture on a blank piece of paper. Compared to other tools used to measure perceptions of scientists, the DAST has a number of advantages, namely, it can be applied quickly and easily, does not require literacy, and allows individuals to express their thoughts while reducing the possibility of recording socially desirable answers (Ocal, 2007). Moreover, since DAST is not based on verbal responses, it can be used easily with young children (Ocal, 2007). Considering the ages of the 
Yagmur Gokbulak \& Burcu Senler, Developing Scientific Practices in Primary School: Benzene Ring...

participating students, this study utilized DAST as the most appropriate tool for measuring thoughts and perceptions about scientists.

\section{Posters}

Students were asked to form groups and create posters for two subjects in the science curriculum that reflected components of the BRH. Students were free to create their posters without any intervention by the teacher, who was also one of the researchers, who offered only limited guidance after assigning the topics to be addressed in the posters, namely "The Effects of Force on Objects" and "Sound Pollution".

\section{Data Collection Process}

Data collection was completed in four weeks in the 2019-2020 academic year. During the first week of the study, the researcher informed the students that the study activities would start by having them answer three open-ended questions. The researcher read the questions aloud and wrote them on the board so that all the students could see and copy them. Students wrote down their answers to the questions along with their names and the date. Next, the DAST was applied by asking the students to imagine a scientist and what the scientist did in the work environment. Students were then told to turn over their papers and to draw the picture they had in their minds. Finally, students were assigned the subject "The Effects of Force on Objects".

During the second week, the researcher explained the BRH to the students, who were then asked to form 3 groups of 3 individuals and to come up with a group name. Next, the researcher led an activity designed to reinforce the BRH by having students match cards that featured the titles of the BRH components with sentences relating to these components. After this activity, students began preparing posters for the subject "The Effects of Force on Objects", and they were reminded by the researchers that they were free to design the posters any way they wanted.

During the third week, the groups finished preparing their posters and then selected one spokesperson per group to present the posters to the class. Following the presentations, the students were assigned the next subject, "Questioning the Causes of Noise Pollution".

During the fourth week, the students completed their posters on "Questioning the Causes of Noise Pollution" and presented them to their classmates. After the presentations, they were asked to repeat the DAST on a blank piece of paper.

\section{Data Analysis}

Qualitative data obtained from the open-ended questions were analyzed using content analysis. Qualitative data obtained from the DAST were analyzed using the Draw-a-Scientist Test Checklist (Finson, Beaver, \& Cramond, 1995). Qualitative data obtained from the posters 
were analyzed using a rubric prepared by the researcher containing 5 criteria based on the following BRH components:

- The appropriateness of the statement written for "Real-world"

- The appropriateness of the statement written for "Prediction"

- The appropriateness of the statement written for "Activities"

- The appropriateness of the statement written for "Data"

- The appropriateness of the statement written for "Explanation"

Each criterion received 1-4 points (4-excellent, 3-good, 2-fair, and 1-needs to improve); accordingly, the lowest possible total score was 5 and the highest was 20. While the interpretation of the scores obtained from the rubric were "1-5" as needs to improve, "6-10" as fair, "11-15" as good, and "16-20" as excellent.

The scoring reliability for the DAST and the poster was assessed using the formula [Reliability = Consensus / (Consensus + Disagreement)] put forward by Miles and Huberman (1994) and was calculated as $87 \%$ and $91 \%$ respectively.

\section{RESULTS}

\section{Open-Ended Questions Findings}

In response to the first open-ended question, "What do you think science is? What comes to mind when you think of science?" students mentioned inventions ( $f=4)$, scientists $(f=1)$, observation ( $f=2)$, research ( $f=2)$, space $(f=2)$, and using a magnifying glass $(f=1)$. They stated that when they thought of "science", inventions and scientists came to mind. The sample sentences written in response to the question are as follows:

"Science can magnify everything, make inventions." (S1)

"Science is research. It is inventing things." (S3)

"Science observes animals." (\$9)

In response to the second open-ended question, "How can scientific knowledge be obtained?" students stated that scientific knowledge was obtained by making inventions ( $f=2$ ), thinking ( $f=2)$, reading $(f=2)$, investigating $(f=3)$, observing $(f=1)$, and experimenting $(f=1)$. The sample sentences written in response to the question are as follows:

"It is necessary to research and observe to obtain scientific knowledge." (S4)

"Scientists produce scientific knowledge by thinking." (\$8) 
Yagmur Gokbulak \& Burcu Senler, Developing Scientific Practices in Primary School: Benzene Ring...

In response to the third open-ended question, "How do scientists work?/What do they do?" students stated that scientists worked by investigating $(f=3)$, going into space $(f=1)$, doing everything $(f=1)$, making inventions $(f=1)$, inventing robots $(f=3)$, and inventing planes $(f=3)$. The sample sentences written in response to the question are as follow:

"Scientists make inventions by research, they build robots." (S3)

\section{DAST Findings}

The findings regarding the change in student perceptions of scientists as observed through student drawings before and after the application of BRH applications are presented in Table 1, which provides data about thoughts and perceptions on the gender, age, and physical appearance of scientists as well as their workplace, the tools they use, and the activities they perform.

Table 1. Frequency distribution of scientists drawn according to gender, age, physical appearance, location, equipment and activities they perform

\begin{tabular}{|c|c|c|c|c|}
\hline & & & $\begin{array}{l}\text { Pre-test } \\
\text { (frequency) }\end{array}$ & $\begin{array}{l}\text { Post-test } \\
\text { (frequency) }\end{array}$ \\
\hline \multirow[t]{2}{*}{ Gender } & Female & & 5 & 5 \\
\hline & Male & & 4 & 4 \\
\hline \multirow[t]{3}{*}{ Age } & Young & & 9 & 9 \\
\hline & Middle Age & & - & - \\
\hline & Senior & & - & - \\
\hline Physical & Messy looking & & 3 & 2 \\
\hline \multirow[t]{2}{*}{ Appearance } & Neat looking & & 5 & 6 \\
\hline & With glasses & & 1 & 1 \\
\hline \multirow[t]{5}{*}{ Residential } & Indoor & Laboratory & 4 & 5 \\
\hline & & Investigating & 2 & 1 \\
\hline & & Room & & \\
\hline & Outdoor & Garden & - & 2 \\
\hline & & Field & 3 & 1 \\
\hline \multirow[t]{7}{*}{ Tools } & Experiment / Field & Tubes & 20 & 18 \\
\hline & symbols & Baker & - & 1 \\
\hline & & Flask & 8 & 4 \\
\hline & & Magnet & - & 1 \\
\hline & & Rocket & 1 & 1 \\
\hline & & Helicopter & 1 & - \\
\hline & & Robot & 3 & 1 \\
\hline
\end{tabular}




\begin{tabular}{llll} 
& Table & 5 & 5 \\
& Pilot & 1 & - \\
& Sky & 1 & - \\
& Bird & - & 2 \\
& Tree & - & 2 \\
Knowledge symbols & Book & 31 & 15 \\
& Notebook & - & 1 \\
& Eraser & - & 1 \\
& Pencil & 2 & 1 \\
& Defter & - & 1 \\
\hline Activity & Bookshelf & 1 & 1 \\
& Experiment & & 7 \\
Observation & & 2 & 3 \\
\hline
\end{tabular}

As the table shows, the number of female scientists ( $f \_1=5, f \_2=5$ ) and the number of male scientists ( $f \_1=4, f_{-} 2=4$ ) portrayed did not change after the BRH activity. All the drawings portrayed scientists as young ( $f_{-} 1=9, f_{-} 2=9$ ) and most often with a neat-looking physical appearance (f_l $\left.1=5, f \_2=6\right)$. Most scientists were drawn in enclosed areas, mainly representing a laboratory environment ( $f \_l=4, f \_2=5$ ).

Regarding tools and equipment used by scientists, most drawings featured symbols related to experimentation-mainly test tubes $\left(f_{-} 1=20, f_{-} 2=18\right)$ and flasks $\left(f_{-} 1=8, f_{-} 2=4\right)$-and to information-mainly books ( $\left.f_{-} 1=31, f_{-} 2=15\right)$. Finally, when the activities of scientists in the working environment were examined, the majority of scientists were drawn as conducting experiments (f_l=7, f_2 $=6$ ).

\section{Posters Findings}

Findings regarding the student posters are presented in Table 2.

Table 2. Rubric scores of the posters in Application I and Application II

\section{Application I \\ Application II}

\begin{tabular}{lcccccc}
\multicolumn{1}{c}{ Criteria } & $\begin{array}{c}\text { Group } \\
\text { A }\end{array}$ & $\begin{array}{c}\text { Group } \\
\text { Storm }\end{array}$ & $\begin{array}{c}\text { Group } \\
\text { Flash }\end{array}$ & $\begin{array}{c}\text { Group } \\
\text { A }\end{array}$ & $\begin{array}{c}\text { Group } \\
\text { Storm }\end{array}$ & $\begin{array}{c}\text { Group } \\
\text { Flash }\end{array}$ \\
\hline $\begin{array}{l}\text { The appropriateness of the statement } \\
\text { written for "Real-world" }\end{array}$ & 3 & 3 & 3 & 4 & 4 & 4 \\
$\begin{array}{l}\text { The appropriateness of the statement } \\
\text { written for "Prediction" }\end{array}$ & 4 & 3 & 3 & 3 & 3 & 4
\end{tabular}


Yagmur Gokbulak \& Burcu Senler, Developing Scientific Practices in Primary School: Benzene Ring...

\begin{tabular}{|c|c|c|c|c|c|c|}
\hline $\begin{array}{l}\text { The appropriateness of the statement } \\
\text { written for "Activities" }\end{array}$ & 3 & 2 & 4 & 3 & 2 & 4 \\
\hline $\begin{array}{l}\text { The appropriateness of the statement } \\
\text { written for "Data" }\end{array}$ & 3 & 3 & 3 & 3 & 4 & 3 \\
\hline $\begin{array}{l}\text { The appropriateness of the statement } \\
\text { written for "Explanation" }\end{array}$ & 2 & 2 & 2 & 2 & 4 & 3 \\
\hline Total & 15 & 13 & 15 & 15 & 31 & 18 \\
\hline
\end{tabular}

As Table 2 displays, prior to the BRH science lessons, all three groups had "good" scores (Group $A p=15$ and Group Storm: $p=13$; Group Flash: $p=15)$. After the BRH science lessons, scores for Group Storm ( $p=17$, "excellent") and Group Flash increased ( $p=18$, "excellent"), while the score for Group A remained the same ( $p=15$, "good"). Regarding the changes in the scores on the individual questions related to the BRH following the science lessons, the score for "Appropriateness of the Expression Written for Real-World" increased by one point for all three groups; the score for "Appropriateness of the Expression Written for Estimation" decreased by one point in Group A and increased by one point in Group Flash; the score for "Appropriateness of the Expression Written for Activities" did not change in any of the groups; the score for "Appropriateness of the Expression Written for Data" increased by one point in Group Storm; and the score for "Appropriateness of the Expression Written for Explanation" increased by one point in Group Flash and by two points in Group Storm.

\section{DISCUSSION}

The study revealed that according to the students, science is defined as making inventions, researching, repairing, and exploring space. This definition of science is similar to those of students from Turkey and five other countries who participated in a study by Dogan (2015), who reported that students from Turkey defined science as knowledge/knowing, researching, experimenting, inventing, and discovering; students from Italy defined science as inventing, discovering, and examining; students from England defined science as experimenting; students from Slovenia defined science as discovering, inventing, learning, and knowing; students from Estonia defined science as researching, knowledge/knowing, and experimenting; and students from Poland defined science as discovering, inventing, learning, and knowledge/knowing.

Additionally, the students expressed the belief that scientific knowledge was obtained by thinking, reading, researching, observing, experimenting, and watching. Previous studies have reported similar findings from different study groups. For example, according to Kaya, Afacan, Polat, and Urtekin (2013), secondary-school students stated that scientific knowledge should be based on science, be provable, and be obtained through experimentation, and a study 
by Kenar (2008) reported that among a group of pre-service teachers, $99 \%$ stated that experiments are necessary for the development of scientific knowledge. These findings suggest that student perceptions of scientific knowledge are shaped at an early age and that this acquired knowledge is permanent.

Regarding the students' perception of scientists, they tended to portray scientists as young, which is similar to the findings reported by Atas and Senler (2018) as well as by Bayram (2018), who described scientists as appearing to be between the ages of 25-50. This could be a result of how students saw scientists portrayed in the media, which usually presents scientists as relatively young. In terms of physical appearance, students in this study portrayed scientists as neat-looking, which is similar to the findings of Atas \& Senler (2018). Also, scientists were portrayed as women. This conflicts with many previous studies (e.g. Atas \& Senler, 2018; Bayram, 2018; Çeliker \& Avci, 2015; Kemaneci, 2012; Ozsoy \& Ahi, 2014) in which students tended to draw scientists as males. The difference could be due to the fact that in the present study, the majority of the participating students were female. Besides, students stated that scientists conduct research and generally work on robots, inventions, aircraft, etc. Similarly, Kibar-Kavak (2008) reported "experimenting", "inventing", and "doing research" to be the most frequent responses of students asked to describe the work carried out by scientists. In another study conducted by Nuhoglu and Afacan (2011) that aimed to evaluate what 4th-, 5th- and 6th-grade students' thoughts about scientists, the students stated that intelligence and curiosity are the most important characteristics of a scientist, that scientists like to do research, and that scientists study physics and chemistry. In a study conducted with six-yearolds, Guler and Akman (2006) reported that according to the participating children, scientists generally prepare formulas in the laboratory, examine them with a telescope or microscope, and conduct experiments. Moreover, according to the students, scientists work in a laboratory with materials such as test tubes and flasks. Other previous studies such as Atas \& Senler (2018), Bayram (2018), Çeliker and Avci (2015), Kucuk and Bag (2012), and Ozsoy and Ahi (2014) also reported that students portrayed scientists as working in a laboratory, whereas Kemaneci (2012) found students drew scientists without depicting them in any specific location. Furthermore, Atas and Senler (2018), Kemaneci(2012), and Ozsoy and Ahi (2014) also reported that student drawings included objects such as flasks and test tubes. In this regard, students might have been influenced by the media and by textbooks, which portray scientists as working in laboratories.

The results show that all three groups had "good" scores in total, namely the appropriateness of the statement written for "Real-World", "Prediction", "Activities", "Data", and "Explanation" in the initial activity. However, all three student groups had difficulty in understanding the "Explanations" component. The difficulties may be because the explanation is challenging for young students. In the second application, one group (A) still had difficulties with this 
Yagmur Gokbulak \& Burcu Senler, Developing Scientific Practices in Primary School: Benzene Ring...

component, while another group (Storm) had difficulty understanding the "Activities" component. Thus, students generally developed an understanding of scientific practices in $\mathrm{BRH}$, especially for the "Real-World" component. This result implies that the students understood scientific practices and their connection to the "real-world" which may raise awareness of the ontological commitments of science and scientists. Even though the students still had certain problems understanding the components of the BRH when involved in the second application, a comparison of the results of the first and second poster applications indicated a certain amount of improvement. Erduran and Dagher (2014) stated that positioning scientific practices only as the epistemic practice of science will lead science education to a process that is far from thinking, memorized and followed step by step. In this study, cognitive and social aspects of scientific practices were stressed by giving examples in classrooms. Hence, it can be said that students had an understanding of the holistic feature of scientific practices.

\section{CONCLUSIONS}

This study aims to develop student understanding of the scientific practices in the BRH and to identify how this process affected student perceptions about science, scientific knowledge and scientists. As some of the above-mentioned findings suggest, student perceptions of science, scientists, and scientific knowledge are shaped at a young age. In this sense, the attitudes of families towards science are important in terms of shaping science in the minds of young students, as are the attitudes of classroom and science teachers, their thoughts, and the written and oral content presented to students in the learning environment, including the information contained in textbooks. In addition, the media plays a very important role in stereotyping the images of scientists(Yontar-Togrol, 2000). Thus, the content presented in the media must shape student perceptions and attitudes towards science positively.

The activity of "scientists in the classroom" which gives chance students to meet a scientist is beneficial for them to learn their profession first hand. Having a scientist in the classroom, discussing scientific expertise by emphasizing BHR might influence not only students' perception of science, scientific knowledge, and scientists but also their understanding of scientific practices.

Furthermore, according to Karabas' (2017) study, young students can engage in scientific practices. Therefore, including scientific practices in instruction, making an environment where students can do similar activities that scientists do, and pointing out the BHR might be effective ways to teach scientific practices.

Considering the relative lack of studies on the Benzene Ring Heuristic (BRH), conducting future research using the $\mathrm{BRH}$ can make a considerable contribution to the literature, especially if the 
research looks at more diverse study populations. Moreover, increasing the number of repeat implementations of the poster activity as well as the interval of time between implementations in future studies could help to better understand the effects of using BRH in science education by allowing students more time to grasp the subject.

\section{REFERENCES}

Atas, Y., \& Senler, B. (2018). İlkokulda benzen halkası benzetmesi uygulaması [Benzene Ring Heuristic application in primary school]. 13. Ulusal Fen Bilimleri ve Matematik Eğitimi Kongresi. Pamukkale Üniversitesi.

Bayram, E. B. (2018). Scientist image of primary school 4th grade students and the role of textbooks and teachers in the formation of these images, (Master's Thesis). Bayburt University.

Cakici, Y. (2013). A prerequisite in science education: Understanding nature of science. Marmara University Ataturk Education Faculty Journal of Educational Sciences, 2013(29), 57-74. Retrieved from https://dergipark.org.tr/en/pub/maruaebd/issue/370/2114

Chambers, D. W. (1983). Stereotypic images of the scientist: The draw a scientists test. Science Education, 67(2), 255-265. https://doi.org/10.1002/sce.3730670213

Cilekrenkli, A. (2019). Teaching reconceptualized family resemblance approach to nature of science in lower secondary classroom, (Master's Thesis). Bogazici University.

Çeliker, H. D., \& Avci, D. E. (2015). Scientist perception of primary school students: How does attendance to scientific activities affect scientist perception? Mehmet Akif Ersoy University Journal of Education Faculty, 2015(36), 90-104. Retrieved from https://dergipark.org.tr/en/download/article-file/181544

Dogan, H. (2015). A study of science and scientist, focussing on the perceptions of 11 to 13 year old students from different countries (Master's Thesis). Akdeniz University.

Driver, R., Leach, J., Millar, R., \& Scott, P. (1996). Young people's images of science. Buckingham: Open University Press.

Erduran, S., \& Dagher, Z. R. (2014). Reconceptualizing nature of science for science education. In Reconceptualizing the nature of science for science education: Scientific knowledge, practices and other family categories. Dordrecht: Springer.

Erduran, S., \& Jimenez-Aleixandre, M. P. (Eds.). (2008). Argumentation in science education. Perspectives from classroom-based research. Dordrecht: Springer.

Finson, K. D., Beaver, J. B., \& Cramond, B. L. (1995). Development and field test of a checklist 
Yagmur Gokbulak \& Burcu Senler, Developing Scientific Practices in Primary School: Benzene Ring...

for the Draw-a-Scientist Test. School Science and Mathematics, 95(4), 195-205. https://doi.org/10.1111/j.1949-8594.1995.tb15762.x

Guler, T., \& Akman, B. (2006). 6 year old children's views on science and scientists. Hacettepe University Journal of Education Faculty, 2006(31), 55-66. Retrieved from http://www.efdergi.hacettepe.edu.tr/yonetim/icerik/makaleler/830-published.pdf

Irzlk, G., \& Nola, R. (2014). New directions for nature of science research. In M. R. Matthews (Ed.), International Handbook of Research in History, Philosophy and Science Teaching (pp. 999-1021). Dordrecth: Springer.

Karabas, N. (2017). The effect of scientific practice-based instruction on seventh graders' perceptions of scientific practices, (Master's Thesis). Bogazici University.

Kaya, E., \& Erduran, S. (2016a). From FRA to RFN, or how the Family Resemblance Approach can be transformed for science curriculum analysis on nature of science. Science \& Education, 25(9), 1115-1133. https://doi.org/10.1007/s11191-016-9861-3

Kaya, E., \& Erduran, S. (2016b). Reconceptualized "Family Resemblance Approach": A holistic perspective on nature of science in science education. The Journal of Turkish Science Education, 13(2), 76-89. https://doi.org/10.12973/tused.10180a

Kaya, E., Erduran, S., Akgun, S., \& Aksoz, B. (2017). Nature of science in teacher education: A holistic approach. Necatibey Faculty of Education Electronic Journal of Science and Mathematics Education, 11 (2), 464-501. https://doi.org/10.17522/balikesirnef.373423

Kaya, V. H., Afacan, O., Polat, D., \& Urtekin, A. (2013). Ilkogretim ogrencilerinin bilim insani ve bilimsel bilgi hakkindaki gorusleri (Kirsehir ili ornegi) [The primary school students' views on scientists and scientific knowledge (Sample of Kırşehir)]. Ahi Evran Universitesi Kirsehir Egitim Fakultesi Dergisi, 14(1), 305-325. Retrieved from https://dergipark.org.tr/en/download/article-file/1490669

Kemaneci, G. (2012). Searching for the image of scientists from the point of view of gifted students, (Master's Thesis). Gazi University.

Kenar, Z. (2008). Prospective science teachers' views of the nature of science, (Master's Thesis). Balikesir University.

Kibar-Kavak, G. (2008). Factors affecting the attitudes and perception of the students towards science and scientists, (Master's Thesis). Selcuk University.

Kucuk, M., \& Bag, H. (2012). A comparison of the 4 and 5. grade students' scientist images. Journal of Bayburt Education Faculty, 7(2), 125-138. https://doi.org/https://dergipark.org.tr/en/download/article-file/215076

Kuhn, D., Arvidsson, T. S., Lesperance, R., \& Corprew, R. (2017). Can engaging in science 
practices promote deep understanding of them? Science Education, 101 (2), 232250. https://doi.org/10.1002/sce.21263

Lederman, N. G. (1992). Students' and teachers' conceptions of the nature of science: A review of the research. Journal of Research in Science Teaching, 29(4), 331-359. https://doi.org/10.1002/tea.3660290404

Lederman, N. G., Lederman, J. S., \& Antink, A. (2013). Nature of science and scientific inquiry as contexts for the learning of science and achievement of scientific literacy. International Journal of Education in Mathematics, Science and Technology, 1 (3), 138-147. Retrieved from https://www.ijemst.net/index.php/ijemst/article/download/19/19

Lederman, N. G., \& Zeidler, D. L. (1987). Science teachers' conceptions of the nature of science: Do they really influence teaching behavior? Science Education, 71 (5), 721734. https://doi.org/10.1002/sce.3730710509

Matthews, M. (2004). Changing the focus: From nature of science (NOS) to features of science (FOS). In M. S. Khine (Ed.), Advances in nature of science research: Concepts and methodologies (pp. 3-26). Dordrecht: Springer.

Merriam, S. (2002). Qualitative practice in research. San Francisco: Jossey-Bass.

Miles, M. B., \& Huberman, A. M. (1994). Qualitative data analysis: an expanded sourcebook (2nd ed.). California: Sage Publications.

Ministry of National Education of Turkey. (2018). Fen Bilimleri Dersi Öğretim Programı, 3-8. Sınıflar. [Science Curriculum (3th-8th grade)]. Ankara: TTKB.

National Research Council [NRC]. (2012). framework for K12 science education: Practices, cross cutting concepts, and core ideas. Washington: National Academies Press.

Nuhoğlu, H., \& Afacan, Ö. (2011). Evaluation of the primary school students' view about scientists. Ahi Evran University Journal of Kirsehir Education Faculty, 12 (3), 279-298. Retrieved from https://dergipark.org.tr/en/pub/kefad/issue/59494/855139\%0A

Ocal, E. (2007). Identification and description of 6, 7, 8 secondary school student's scientist image and schema, (Master's Thesis). Gazi University.

Ozsoy, S., \& Ahi, B. (2014). Images of scientists through the eyes of the children. Necatibey Faculty of Education Electronic Journal of Science and Mathematics Education, 8(1), 204-230. https://doi.org/10.12973/nefmed.2014.8.1.a9

Peters, M. A. (2006). Special issue - Philosophy of science education. Educational Philosophy and Theory, 38(5), 579-584. https://doi.org/10.1111/j.1469-5812.2006.00223 
Yagmur Gokbulak \& Burcu Senler, Developing Scientific Practices in Primary School: Benzene Ring...

Roberts, D. A. (2007). Scientific literacy/Science literacy. In S. K. Abell \& N. G. Lederman (Eds.), Handbook of research on science education (pp. 729-780). London: Lawrence Erlbaum Associates.

Senel, T., \& Aslan, O. (2014). The metaphoric perceptions of preservice early childhood teachers conceptions on science and scientist. Mersin University Journal of Education Faculty, 10(2), 77-95. Retrieved from https://dergipark.org.tr/en/pub/mersinefd/issue/17394/181827\%0A

Stroupe, D. (2015). Describing "science practice" in learning settings. Science Education, 99(6), 1033-1040. https://doi.org/10.1002/sce.21191

Yontar-Togrol, A. (2000). Ogrencilerin bilim insani ile ilgili imgeleri [Student images of the scientist]. Education and Science, 25(118), 49-57. 